\title{
Chitin Biosynthesis Inhibitors in Euschistus heros Fabr. (Hemiptera: Pentatomidae): Morphometric Alterations in Testes and Nuclei of Testicular Accessory Cells of Adults
}

\author{
Paulo Sérgio Gimenez Cremonez ${ }^{1}$, Samuel Pagnoncelli Gouvea ${ }^{1}$, Daniela Oliveira Pinheiro ${ }^{2}$, \\ Ângela Maria Ferreira Falleiros ${ }^{2}$, Sheila Michele Levy ${ }^{2}$, Ana Maria Meneghin ${ }^{3}$, Inês Cristina de Batista Fonseca ${ }^{1}$ \\ $\&$ Pedro Manuel Oliveira Janeiro Neves ${ }^{1}$ \\ ${ }^{1}$ Department of Agronomy, State University of Londrina, Londrina, Brazil \\ ${ }^{2}$ Department of Histology, State University of Londrina, Londrina, Brazil \\ ${ }^{3}$ Agronomic Institute of Paraná, Londrina, Brazil \\ Correspondence: Pedro Manuel Oliveira Janeiro Neves, Department of Agronomy, State University of Londrina, \\ Londrina, Brazil. E-mail: pedroneves@uel.br
}

Received: July 17, 2018

doi:10.5539/jas.v11n1p410
Accepted: September 7, $2018 \quad$ Online Published: December 15, 2018

URL: https://doi.org/10.5539/jas.v11n1p410

\begin{abstract}
Euschistus heros is an important pest in Brazilian agriculture growing importance in the general Neotropical realm. Its reproductive potential is the key factor for its characterization as a pest in major crops such as soybean and cotton. The aims of this study were to characterize morphometric parameters of testicles and testicular accessory cells-TACs nuclei of adults $E$. heros treated with chitin biosynthesis inhibitors (CBIs). The insecticides lufenuron $\left(\right.$ Match $\left.^{\circledR} 50 \mathrm{EC}\right)$ and buprofezin (Applaud ${ }^{\circledR} 250 \mathrm{WP}$ ) were applied individually in $4^{\text {th }}$ instar nymphs, remained in controlled conditions until the emergence of adult males. The testicles were identified and removed $72 \mathrm{~h}$ after emergency, fixed, photographed for anatomic analysis, and processed for morphometric analyses of the TACs nuclei. It was possible to observe that lufenuron and buprofezin decreased the testicular area. Buprofezin decreased the mean nuclear area analyzed in the TACs, and nuclear hypertrophy can indicate an activity on support and nutrition of germ line cells, presenting a possible effect on protein synthesis. The intense reaction for Fast green in control compared to buprofezin treatment may indicate that total protein (histones and non-histones) has been altered. The tested insecticides, with special focus on buprofezin may affect the final stages of reproductive development of $E$. heros, with potential to be used in field to the control of this pest.
\end{abstract}

Keywords: neotropical-brown stink bug, insect growth disruptor, metamorphosis, testicular accessory cells (TACs)

\section{Introduction}

Testicular accessory cells (TACs), also known as support, follicle, nurse, cystic cells or widely known as Sertoli cells are present in the majority of vertebrates and invertebrate's testicles and may vary in structure and function between the different taxonomic groups (França \& Chiarini-Garcia, 2005). The Sertoli cell nomenclature in invertebrate's studies presents divergence between some authors (Pudney, 1993; Griswold \& McLean 2006). Thus, in this work it will be named as testicular accessory cells, as described by Guraya (1995). In insects, these cells are linked to those cysts in which the germ line cells develop (Hinsch, 1993).

The TACs has been described as highly important for perform different reproductive functions. In addition to the classical function of physical support, these cells have been described to act in nutrition, secretion of substances, endocytosis and hormonal regulation of spermatogenesis (Griswold \& McLean, 2006). However, the physiology of TACs has been still little studied in insects and other arthropods (Hinsch, 1993; Guraya, 1995; Gabała, 2006; Mazzei, Longo, \& Brundo, 2015).

The structure of TACs may present as much variation as its functions. The TACs generally have a columnar shape, extending from the follicular wall (or tunica propria) to the intern cysts, maintaining contact with basal cells, with TACs and with the germ line cells. These cells normally present a single, triangular shaped nucleus, 
composed mostly by euchromatin and generally located in the basal region (Guraya, 1995; França \& Chiarini-Garcia, 2010).

In Heteroptera, many works that assess the morphology and morphometry parameters studied on the germ line cells, with a major focus on the spermatogenesis final processes (Araújo, Lino-Neto, Ramalho, Zanuncio, \& Serrão, 2011; Araújo, Báo, \& Lino-Neto, 2012; Baffa et al., 2017; Novais, Dias, \& Lino-Neto, 2017; Santos \& Lino-Neto, 2018). However, none of them presents focus in the TACs morphometry.

The Neotropical-brown stink bug Euschistus heros Fabricius (Hemiptera: Pentatomidae) became a major agricultural pest in the productive sector in Brazil (Fonseca, Fernandes, Justiniano, Cavada, \& Silva, 2014; Soares, Cordeiro, Santos, Omoto, \& Correa, 2018). The expressive reproductive potential and its proliferative index is the main cause that defined your spread in the area. Significantly reduce insect populations, productivity and quality of seeds in training (Panizzi, Bueno, \& Silva, 2012).

It is known that Chitin Biosynthesis Inhibitors (CBIs) are insect growth disruptors insecticides that affects the process of exocytosis of the intracellular monomer of $N$-Acetylglucosamine (GlcNAc), the basic component of the chitinous structure of the exoskeleton (Merzendorfer, 2006). Some CBIs prevents the ion channels of the vacuolar complex export the GlcNAc monomers out of the cytoplasm and compose the chitin polypeptides (Matsumura, 2010). These products can be used in crop models based on integrated pest management, with characteristics of selectivity and lower toxicity to beneficial insects (Rasdi et al., 2012; Vieira et al., 2012).

The use CBIs in reproductive development of stink bugs pests has been studied before by Agüero et al (2014), with representative results of effects on morphology in Nezara viridula L. (Hemiptera: Pentatomidae), where the authors could detect negative effects on gonad formation in insects treated with diflubenzuron. Also, in another study, female and male reproductive organs of Dichelops melacanthus (Hemiptera: Pentatomidae) were affected by CBIs (Cremonez, Pinheiro, Falleiros, \& Neves, 2017), however the studies relating the effects of insecticides on insects TACs are practically inexistent, especially in adults $E$. heros treated with CBIs.

In this context, the aims of this study were to characterize the morphometric parameters of testicles and TACs nuclei in the testicular follicles of adults E. heros, in addition to determine possible changes in these cells as results of the application of CBIs lufenuron and buprofezin.

\section{Material and Methods}

\subsection{Insect Rearing}

Adults of E. heros were obtained from a colony maintained the Laboratory (Embrapa Soybean- Brazil) and taken to the State University of Londrina (UEL), Brazil. The stink bugs were reared in plastic boxes with perforated cover $(\mathrm{V}=3.75 \mathrm{~L})$, containing pods of organic common beans (Phaseolus vulgaris L.) (Fabaceae), peanuts (Arachis hypogaea L.) (Fabaceae) and soybean (Glycine max Merrill) (Fabaceae) as food ad lib, and cotton wools moistened with distilled water for hydration.

For this study, nymphs of fourth instar (N4) of E. heros (18 \pm 1 days) were collected from the F1 generation of the stablished colony. The insects were maintained under controlled conditions in climatized chamber $\left(26 \pm 1{ }^{\circ} \mathrm{C}\right.$, $65 \pm 5 \% \mathrm{RH}, 14 \mathrm{~h}$ photoperiod).

\subsection{Insecticide Application}

The CBIs were applied in pre-determined sublethal doses $\left(\mathrm{LD}_{30}\right)$, according to the methodology proposed by Zanuncio et al. (2005), as it follows: lufenuron $\left(\mathrm{Match}^{\circledR} 50 \mathrm{EC}\right) \mathrm{LD}_{30}=3.34 \times 10^{-3} \mathrm{~mL}$ a.i. $\mathrm{L}^{-1}$ and buprofezin $\left(\right.$ Applaud $\left.^{\circledR} 250 \mathrm{WP}\right) \mathrm{LD}_{30}=1.12 \times 10^{-3} \mathrm{~g}$ a.i. $\mathrm{L}^{-1}$. The insecticide solutions were diluted to the respective $\mathrm{LD}_{30}$ with distilled water, then applied individually through the topical application of $1 \mu \mathrm{L}$ above the $\mathrm{N} 4$ dorsum with the aid of a micropipette. For the control treatment, it was used pure distilled water.

After the application, the groups of ten $\mathrm{N} 4$, were maintained by a polystyrene-crystal box $(11.0 \times 11.0 \mathrm{~cm})$ containing food and water as described above. The insects that remain alive until adulthood were sexed and the males individualized for the experiment.

\subsection{Testes Collection-Morphology Technique}

Virgin adult males were individualized in Petri dishes $(9 \mathrm{~cm}$ diam.) and after $72 \mathrm{~h}$ of the adult's emergency the males were anesthetized in cold $\left(-4{ }^{\circ} \mathrm{C}\right)$ for $5 \mathrm{~min}$ and dissected in Petri dish. The testicles were identified, removed and immediately fixed in Karnovsky solution (glutaraldehyde $2.5 \%+$ paraformaldehyde $4 \%$ in phosphate buffer solution $\mathrm{pH}$ 7.2) at room temperature by $24 \mathrm{~h}$ and submitted to the procedures described below. 


\subsection{Testes Morphometry}

The removed testes ( $\mathrm{n}=20$ per treatment) were analyzed and photographed in stereoscopic microscope Olympus SZ61 ${ }^{\circledR}$ (Olympus) and the apparent area was bounded and morphometric analyzed according to the proposed methodology of Schneider, Rasband, and Eliceiri (2012), using the ImageJ 1.51k software.

\subsection{Morphometry of the TACs Nuclei}

Five testicles of each treatment fixed in Karnovsky's solution were dehydrated in a gradual sequence of ethyl alcohol and included and embedded in Leica HistoResin ${ }^{\circledR}$ (Leica) using protocol of Insect's Laboratory/Department of Histology/UEL. The cross sections $(5 \mu \mathrm{m})$ were obtained and stained by HE, adapted of Bastos et al. (2018). The sections were analyzed and photographed in the Axiophot ${ }^{\circledR}$ photomicroscope (Zeiss) coupled with a camera Moticam ${ }^{\circledR}$ 3.0 MP (Motic).

The nuclei of the TACs were analyzed through ImageJ, according to Baviskar (2011). The data was obtained by the nuclear area of the TACs present only in the growth zone, where one image was taken on each region of the primary spermatocytes.

Additionally, sections of control and buprofezin treated testicles were stained by Fast green $\mathrm{pH}$ 2.7, analyzed and qualitatively compared in staining intensity according to the methodology of Gifford Jr. and Dengles (1966), and Beerman (2013).

\subsection{Statistical Analysis}

The analysis of area of the adult stink bugs testicles follow the completely randomized design, with three treatments (i.e. lufenuron, buprofezin, distilled water). The values were subjected to Bartlett test of variance homogeneity and to Shapiro-Wilk's analysis of normality, then to analysis of variance and the means compared by Tukey test $(\mathrm{p} \leq 0.05)$.

The TACs nuclei area was followed by the same design, with three treatments (i.e. lufenuron, buprofezin, distilled water) and data observed only in the growth zone of the testicular follicles. Bartlett and Shapiro-Wilk tests were also performed. The values were subjected to mixed linear model for repeated measures analysis (follicle as a random effect) and the treatment means compared by Tukey test $(\mathrm{p} \leq 0.05)$.

The whole process was formatted and processed with the $R \circledR$ software (R Core Team, 2018).

\section{Results}

The testicles of E. heros were identified and each testicle presents six follicles we numbered F1-F6 from the proximal region. It was possible to observe morphological differences among them, more apparent on the spermatozoid bundles. It is possible to observe smaller bundles in F1, F2, F3 and F5, and a more elongated type of spermatozoid in F4 and F6 (Figure 1).

The anatomical size images of testicle showed that the insects with sublethal doses of lufenuron $\left(2.499 \mathrm{~mm}^{2}\right)$ and buprofezin $\left(2.317 \mathrm{~mm}^{2}\right)$ presented smaller organs related to control treatment insects $\left(2.902 \mathrm{~mm}^{2}\right)$, which represents around 14 and $20 \%$ of reduction, respectively (Table 1 ).

Table 1. Mean testicular area and testicular accessory cell (TAC) nuclei area of testicles of adult Euschistus heros males treated with chitin biosynthesis inhibitors applied in 4th instar nymphs under laboratory conditions

\begin{tabular}{|c|c|c|c|c|}
\hline \multirow{2}{*}{ Treatment } & \multicolumn{2}{|r|}{ Testicle } & \multicolumn{2}{|c|}{ Testicular accessory cells } \\
\hline & $\mathrm{N}$ & Area $\left(\mathrm{mm}^{2} \pm \mathrm{SE}\right)$ & $\mathrm{N}$ & Nuclear area $\left(\mu \mathrm{m}^{2}\right)$ \\
\hline Control (distilled water) & 20 & $2.902 \pm 0.155 \mathrm{a}$ & 213 & $57.796 a$ \\
\hline Lufenuron $\operatorname{LD}_{30}\left(3.34 \times 10^{-3} \mathrm{~mL}\right.$ a.i. $\left.\mathrm{L}^{-1}\right)$ & 20 & $2.499 \pm 0.128 b$ & 182 & $52.904 \mathrm{a}$ \\
\hline Buprofezin $\operatorname{LD}_{30}\left(1.12 \times 10^{-3}\right.$ g a.i. $\left.\mathrm{L}^{-1}\right)$ & 20 & $2.317 \pm 0.090 \mathrm{~b}$ & 177 & $46.243 b$ \\
\hline
\end{tabular}

Note. means followed by the same letter in the column did not significantly differ by Tukey test $(\mathrm{p} \leq 0.05) . \mathrm{N}=$ number of measures; $\mathrm{SE}=$ standard error; $\mathrm{LD} 30$ = sublethal dose; a. i. = active ingredient. 


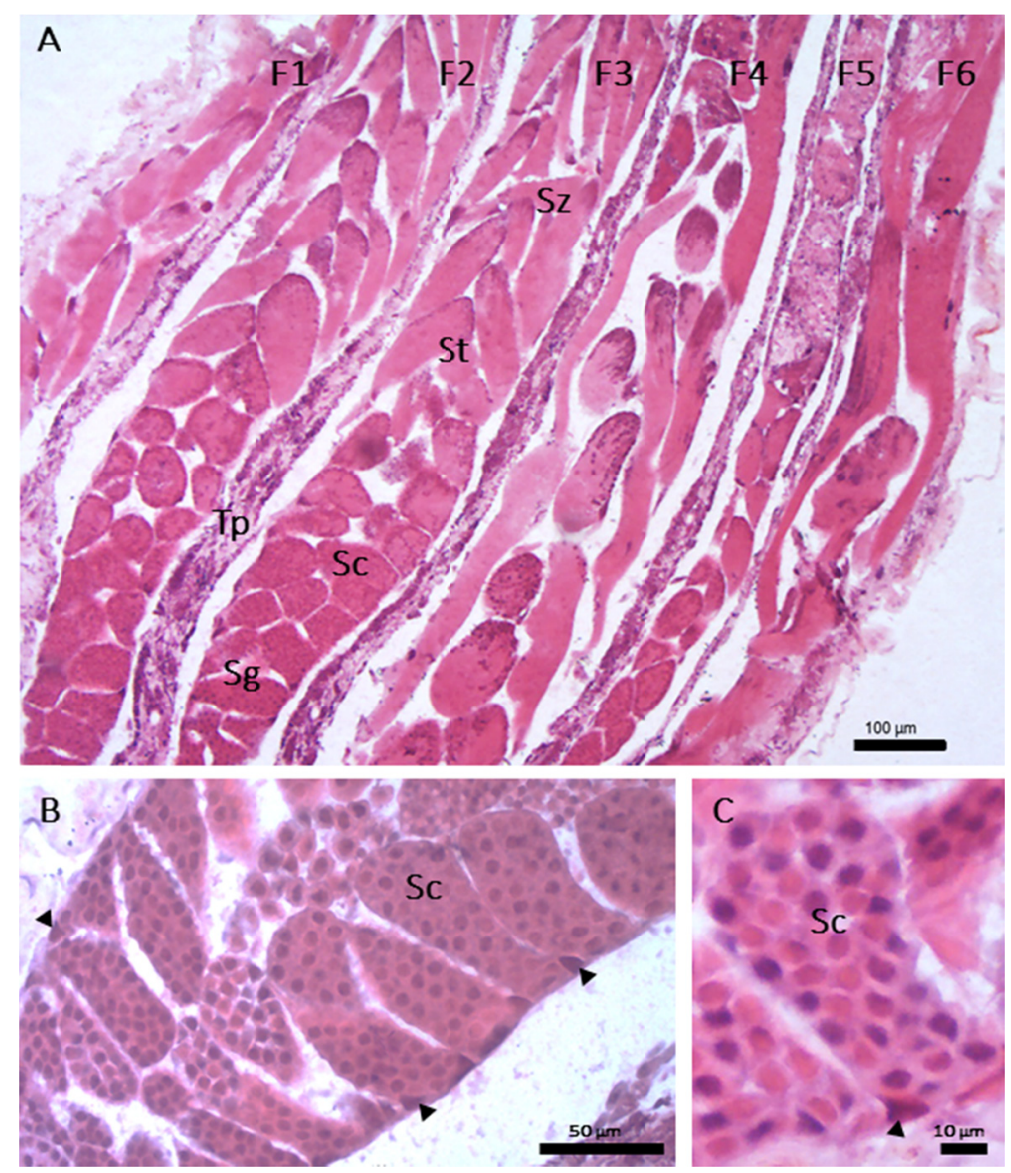

Figure 1. Testicle of adult Euschistus heros. A) The six testicular follicles (F1-F6) evidencing the main regions of spermatogenesis and the polymorphism between them. B) Zone of growth showing the region of spermatocytes cysts (Sc) with the nuclei (arrowhead) of testicular accessory cells (TACs). C) A spermatocyte cyst (Sc) and nucleus (arrowhead) of a TAC. Sg: spermatogonia; St: spermatid bundles; Sz: spermatozoid bundles; Tp: tunica propria. Stained by HE

The testicular accessory cells (TACs) nuclei were identified in all six follicles and in all stages of development of the germ cells. Apparently, a single nucleus is located at the base of the TAC, in proximity to the tunica propria. These nuclei are typically triangular to irregular shaped, with evident nucleoli heavily stained with haematoxylin (Figure 1).

The morphometric results of TACs nuclei show that buprofezin reduced significantly the development of these cells $\left(46.243 \mu \mathrm{m}^{2}\right)$ comparing to the control $\left(57.796 \mu \mathrm{m}^{2}\right)$ (Table 1). It is not possible to observe the same aspect comparing the control with the lufenuron treatment $\left(52.904 \mu \mathrm{m}^{2}\right)$ (Table 1).

It was possible to detect positive reaction Fast green $\mathrm{pH} 2.7$ more intense in the control treatment $(+++)$ compared to the buprofezin treatment $(++)$ in TACs cytoplasm as well as in all germ cell cytoplasm (Table 2). Lufenuron data were not included in this method due to verification of the morphometric analysis, since it not presented significant difference. 
Table 2. Intensity of Fast green $\mathrm{pH} 2.7$ staining reaction in follicle germ line cells cytoplasm in testicles of adult Euschistus heros males treated with Chitin Biosynthesis Inhibitors applied in 4th instar nymphs under laboratory conditions

\begin{tabular}{ll}
\hline Treatment & Intensity of Reaction \\
\hline Control (distilled water) & +++ \\
Buprofezin $\mathrm{LD}_{30}\left(1.12 \times 10^{-3} \mathrm{~g}\right.$ a.i. $\left.\mathrm{L}^{-1}\right)$ & ++ \\
\hline
\end{tabular}

Note. Degrees of intensity of staining by Fast green $\mathrm{pH} 2.7$; Moderated positive reaction $=++$; intense positive reaction $=+++$. These data represent qualitative estimates based on germ line cells photomicrographs from comparable regions with $5 \mu \mathrm{m}$ of thickness.

\section{Discussion}

The testes of E. heros are anatomically paired, connected to an ejaculatory common duct by vas deferens as described for other Pentatomidae insects (Araújo et al., 2011; Cremonez et al., 2017). The morphological differences between the testicular follicles of E. heros were previously observed (Souza \& Itoyama, 2010; Aguiar et al., 2017), demonstrating that F1, F2 and F3 are regular sized follicles, while F4 and F6 are slightly larger and F5 is much thinner than the others.

The difference between follicles were related to the polymorphism of sperm and cells of the germ line, also observed in other Hemiptera (Araújo et al., 2011, 2012; Barcellos, Cossolin, Dias, \& Lino-Neto, 2017; Santos \& Lino-Neto, 2018). In E. heros this polymorphism was analyzed using transmission electronic microscopy (TEM) (Cossolin, 2015), evidencing a type I sperm present in F1, F2 and F3, a type II present in the follicle F5, and a type III sperm present in the follicles F4 and F6.

In addition to the direct action on the development of the target pest, lufenuron and buprofezin also affects the neuroreceptor of acetyl-cholinesterase (Doucet \& Retnakaram, 2012). These factors, combined with the classical effect of uneven distribution of GlcNAg in chitin structure by failures of the activity of chitin synthase (Merzendorfer, 2013; Campbell, Baldwin, \& Koehler, 2017) can affect the normal development and physiology of the targeted insect. A study showed that lufenuron caused high mortalities over nymphs of $E$. heros but did not affected the adult's fecundity or their eggs fertility (Turchen, Hunhoff, Viana, \& Pereira, 2016).

In works with different insecticides was observed reproductive alterations. Imidacloprid significantly reduced the volume of adult testicles of Blattella germanica L. (Blattodea: Blattellidae) (Messiad, Habes, \& Soltani, 2015), while over males of E. heros presented higher reproductive rates and increased metabolic and locomotor activity, however, the testicles have not changed in size (Haddi et al., 2016). The mixture thiamethoxam + lambda-cyhalothrin did not affected the spermatogenesis nor reproductive organs structure of $E$. heros over 15 generations (Aguiar et al., 2017). In this study, the morphometric alterations in testicular area suggests the action of the CBIs over reproductive development in the final stages of E. heros growth.

Larger nuclei are characteristics of cells with higher activity in protein synthesis (Alberts et al., 2014). Additionally, it is known that buprofezin presents a slightly action suppressing DNA synthesis (Dhadialla, Retnakaran \& Smagghe, 2010). The alterations in the TACs nuclei area suggests the effects of buprofezin over these cells and may affects the nutrition and structure of the germ line cells, probably affecting the male reproductive performance, as observed previously in D. melacanthus (Cremonez et al., 2017).

The intense positive reaction of Fast green $\mathrm{pH} 2.7$ in control testes compared to buprofezin treatment may indicate that total protein (histones and non-histones) has been reduced with this CBI, probably relating the nuclei hypertrophy to the protein synthesis in the testes, and future studies may be conducted to better elucidate these findings.

Buprofezin is recommended for control of hemipteran pests of the suborders Sternorrhyncha and Auchenorrhyncha (Naranjo, Ellsworth, \& Hagler, 2004; Prabhaker \& Toscano, 2007). The main effects of buprofezin over E. heros suggest it is efficient to suppress populations of Heteroptera as well, mainly to affect the reproductive aspects of the stink bug.

The CBIs lufenuron and buprofezin presented potential for population control of the Neotropical brown stink bug. This study shows a possible direct activity of buprofezin on protein synthesis and an indirect action on the germ line cells. Other studies may be conducted to elucidate the CBIs action over E. heros reproduction and viability. 


\section{Acknowledgements}

The authors thank J. J. Silva and S. Roggia of Embrapa Soybean, and the Laboratory of Entomology of IAPAR, for the concession of the insects, to the Agronomy and Histology Department of UEL for the laboratory support, and CAPES/Araucaria Foundation for the financial support (Process number 88882.168653/2017-01).

\section{References}

Agüero, M. A. F., Neves, P. M. O. J., \& Cremonez P. S. G. (2014). Efeito do piriproxifem e diflubenzurom na reprodução de Nezara viridula. Inv. Agr., 16, 99-106.

Aguiar, R. C. M., Husch, P. E., Gallo, R. B., Levy, S. M., Vilas-Bôas, L. A., Silva, C. R. M., ... Rosa, R. (2017). Effects of thiamethoxam and lambda-cyhalothrin on spermatogenesis of Euschistus heros (Hemiptera: Pentatomidae). Entomol. Sci., 20, 279-287. https://doi.org/10.1111/ens.12257

Alberts, B., Johnson, A., Lewis, J., Morgan, D., Raff, M., Roberts, K., \& Walter, P. (2014). Molecular biology of the cell (6th ed., p. 1464). New York: Garland Science.

Araújo, V. A., Lino-Neto, J., Ramalho, F. S., Zanuncio, J. C., \& Serrão, J. E. (2011). Ultrastructure and heteromorphism in five species of bugs (Pentatomidae: Heteroptera). Micron., 42, 560-567. https://doi.org/ 10.1016/j.micron.2011.02.001

Araújo, V. A., Báo, S. N., \& Lino-Neto, J. (2012). Polymorphism of spermatozoa in Largus rufipennis Laporte 1832 (Heteroptera: Pyrrhocoroidea: Largidae). Acta Zool., 93, 239-244. https://doi.org/10.1111/j.1463-6395. 2011.00559.x

Baffa, A. F., Camara, D. C. P., Santos-Mallet, J. R., Dasilva, E. R., Costa, J., \& Freitas, S. P. C. (2017). Sperm dimorphism in the Triatoma brasiliensis species complex and its applications. Med. Vet. Entomol., 31, 192-199. https://doi.org/10.1111/mve. 12226

Barcellos, M. S., Cossolin, J. F. S., Dias, G., \& Lino-Neto, J. (2017). Sperm morphology of the leafhopper Diaphorina citri Kuwayama (Hemiptera: Sternorhyncha: Psylloidea: Liviidae). Micron, 99, 49-55. https://doi.org/10.1016/j.micron.2017.03.017

Bastos, J. S. Q., Pereira, M. J. B., Costa, M. B., Turchen, L. M., Pinheiro, D. O., \& Cremonez, P. S. G. (2018). Effect toxic and behavioral of Annona mucosa (Annonaceae) on the tomato leaf miner. J. Agric. Sci., 10, 362-371. https://doi.org/10.5539/jas.v10n8p362

Baviskar, S. N. (2011). A quick \& automated method for measuring cell area using ImageJ. Am. Biol. Teach., 73, 554-556. https://doi.org/10.1525/abt.2011.73.9.9

Beermann, W. (2013). Riesenchromosomen(V. 6, p. 162). Berlin: Springer-Verlag.

Campbell, B., Baldwin, R., \& Koehler, P. (2017). Locomotion inhibition of Cimex lectularius L. following topical, sublethal dose application of the chitin synthesis inhibitor lufenuron. Insects, 8, 94. https://doi.org/ $10.3390 /$ insects 8030094

Cossolin, J. F. S. (2015). Polimorfismo e ultraestrutura dos espermatozoides de Euschistus heros (Fabricius, 1798) (Hemiptera: Pentatomidae) (p. 35, Master's thesis, Universidade Federal de Viçosa, Viçosa, Brazil).

Cremonez, P. S. G., Pinheiro, D. O., Falleiros, A. M. F., \& Neves, P. M. O. J. (2017). Performance of reproductive system of Dichelops melacanthus (Hemiptera: Pentatomidae) subjected to buprofezin and pyriproxyfen: Morphological analysis of ovarioles and testis. Semin. Cien. Agrar., 38, 2279-2291. http://doi.org/10.5433/1679-0359.2017v38n4Sup11p2279

Dhadialla, T. S., Retnakaran, A., \& Smagghe, G. (2010). Insect growth- and development-disrupting insecticides. In L. I. Gilbert, \& S. S. Gill (Eds.), Insect control: biological and synthetic agents (p. 470). London: Elsevier Academic Press.

Doucet, D., \& Retnakaran, A. (2012). Insect chitin: metabolism, genomics and pest management. Adv. Insect. Physiol., 43, 437-511. https://doi.org/10.1016/B978-0-12-391500-9.00006-1

Fonseca, P. R. B., Fernandes, M. G., Justiniano, W., Cavada, L. H., \& Silva, J. A. N. (2014). Sequential sampling of adults and nymphs of Euschistus heros (F) (Hemiptera: Pentatomidae) on soybean Bt and non-Bt. $J$. Agric. Sci., 6, 110-117. https://doi.org/10.5539/jas.v6n11p110

França, L. R., \& Chiarini-Garcia, H. (2005). Célula de Sertoli. In H. F. Carvalho, \& C. B. Collares-Buzato (Eds.), Células: uma abordagem multidisciplinary (p. 465). Barueri: Manole. 
Gabała, E. (2006). Diversity of Sertoli cells in the testis of Saduria entomon L. (Crustacea, Isopoda). Invert. Reprod. Dev., 49, 19-28. https://doi.org/10.1080/07924259.2006.9652190

Gifford Jr., E. M., \& Dengler, R. E. (1966). Histones and alkaline Fast green staining of onion roots. Amer. J. Bot., 53, 1125-1132. https://doi.org/10.1002/j.1537-2197.1966.tb06880.x

Griswold, M. D., \& McLean, D. (2006). The Sertoli cell. In J. Neill (Ed.), Knobil and Neill's physiology of reproduction (p. 3230). London; Academic Press. https://doi.org/10.1016/B978-012515400-0/50024-5

Guraya, S. S. (1995). The comparative cell biology of accessory somatic (or Sertoli) cells in the animal testis. Int. Rev. Cyt., 160, 163-220. https://doi.org/10.1016/S0074-7696(08)61555-7

Haddi, K., Mendes, M. V., Barcellos, M. S., Lino-Neto, J., Freitas, H. L., Guedes, R. N. C., \& Oliveira, E. E. (2016). Sexual success after stress? Imidacloprid-induced hormesis in males of the Neotropical stink bug Euschistus heros. PLoS One, 2016, 1-18. https://doi.org/10.1371/journal.pone.0156616

Hinsch, G. W. (1993). Comparative organization and cytology of Sertoli cells in invertebrates. In L. D. Russel, \& M. D. Griswold, (Eds.). The Sertoli cell (p. 826). Clearwater: Cache River Press.

Matsumura, F. (2010). Studies on the action mechanism of benzoylurea insecticides to inhibit the process of chitin synthesis in insects: A review on the status of research activities in the past, the present and the future prospects. Pestic. Biochem. Phys., 97, 133-139. https://doi.org/10.1016/j.pestbp.2009.10.001

Mazzei, V., Longo, G., \& Brundo, M. V. (2015). Testis follicles ultrastructure of three species of terrestrial isopods (Crustacea, Isopoda Oniscidea). Tissue Cell, 47, 456-464. https://doi.org/10.1016/j.tice.2015.07.008

Messiad, R., Habes, D., \& Soltani, N. (2015). Reproductive effects of a neonicotinoid insecticide (Imidacloprid) in the german cockroaches Blatella germanica L. (Dictyoptera: Blatellidae). J. Entomol. Zool. Stud., 3, 1-6.

Merzendorfer, H. (2013). Chitin synthesis inhibitors: old molecules and new developments. Insect Sci., 20, 121-138. https://doi.org/10.1111/j.1744-7917.2012.01535.x

Naranjo, S. E., Ellsworth, P. C., \& Hagler, J. R. (2004). Conservation of natural enemies in cotton: Role of insect growth regulators in management systems for Bemisia tabaci. Biol. Control, 30, 52-72. https://doi.org/ 10.1016/j.biocontrol.2003.09.010

Novais, A. M., Dias, G., \& Lino-Neto, J. (2017). Testicular, spermatogenesis and sperm morphology in Martarega bentoi (Heteroptera: Notonectidae). Arthropod Struct. Dev., 46, 635-643. https://doi.org/10.1016/ j.asd.2017.04.002

Panizzi, A. R., Bueno, A. F., \& Silva, F. A. C. (2012). Insetos que atacam vagens e grãos. In C. B. Hoffmann-Campo, B. S. Corrêa-Ferreira, \& F. Moscardi (Eds.), Soja: Manejo integrado de insetos e outros artrópodes-praga (p. 859). Brasilia: Embrapa.

Prabhaker, N., \& Toscano, N. C. (2007). Toxicity of the insect growth regulators, buprofezin and pyriproxyfen, to the glassy-winged sharpshooter, Homalodisca coagulata Say (Homoptera: Cicadellidae). Crop Protect., 26, 495-502. https://doi.org/10.1016/j.cropro.2006.04.019

Pudney, J. (1993). Comparative citology of the non-mammalian Sertoli cell. In L. D. Russel, \& M. D. Griswold (Eds.), The Sertoli cell (p. 826). Clearwater: Cache River Press.

R Core Team. (2018). R: A language and environment for statistical computing. Vienna: R Foundation for Statistical Computing. Received from https://www.R-project.org

Rasdi, M. Z., Salmah, C. M. R., Hassan, A. A., Hamady, D., Hamaseh, A., \& Ismail, F. (2012). Field evaluation of some insecticides on whitefly (Trialeurodes vaporariorum) and predator (Macrolophus caliginosus) on brinjal and tomato plants. Asian J. Agric. Rural Dev., 2, 302-311.

Santos, A. B. R., \& Lino-Neto, J. (2018). Sperm morphology of predatory pirate bugs Amphiareus constrictus and Blaptostethus pallescens (Heteroptera: Anthocoridae) with phylogenetic inferences. Micron, 105, 18-23. https://doi.org/10.1016/j.micron.2017.11.004

Schneider, C. A., Rasband, W. S., \& Eliceiri, K. W. (2012). NIH Image to ImageJ: 25 years of image analysis. Nat. Methods, 9, 671-675. https://doi.org/10.1038/nmeth.2089

Soares, P. L., Cordeiro, E. M., Santos, F. N., Omoto, C., \& Correa, A. S. (2018). The reunion of two lineages of the Neotropical brown stink bug on soybean lands in the heart of Brazil. Sci. Rep., 8, 2496. https://doi.org/ $10.1038 / \mathrm{s} 41598-018-20187-6$ 
Souza, H. V., \& Itoyama, M. M. (2010). Comparative study of spermatogenesis and nucleolar behavior in testicular lobes of Euschistus heros (Heteroptera: Pentatomidae). Psyche, 2010, 1-10. https://doi.org/ $10.1155 / 2010 / 428673$

Turchen, L. M.; Hunhoff, L. M., Viana, E. S., \& Pereira, M. J. B (2016). Toxicidade de lufenuron sobre ninfas e adultos do percevejo-marrom-da-soja. Braz. J. Agric., 91, 17-25.

Vieira, S. S., Boff, M. I. C., Bueno, A. F., Gobbi, A. L., Lobo, R. V., \& Bueno, R. C. O. F. (2012). Efeitos dos inseticidas utilizados no controle de Bemisia tabaci (Gennadius) biótipo B e sua seletividade aos inimigos naturais na cultura da soja. Semin. Cien. Agrar., 33, 1809-1818. https://doi.org/10.5433/1679-0359.2012 v33n5p1809

Zanuncio, T. V., Zanuncio, J. C., Serrão, J. E., Medeiros, R. S., Pinon, T. B. M., \& Sediyama, C. A. Z. (2005). Fertility and life expectancy of the predator Supputius cincticeps (Hemiptera: Pentatomidae) exposed to sublethal doses of permethrin. Biol. Res., 38, 31-39. https://doi.org/10.4067/S0716-97602005000100005

\section{Copyrights}

Copyright for this article is retained by the author(s), with first publication rights granted to the journal.

This is an open-access article distributed under the terms and conditions of the Creative Commons Attribution license (http://creativecommons.org/licenses/by/4.0/). 